\title{
Immunology and Immunotherapeutic Approaches for Advanced Renal Cell Carcinoma: A Comprehensive Review
}

\author{
Yoon-Soo Hah ${ }^{1}$ (1) and Kyo-Chul Koo ${ }^{2, *(\mathbb{D}}$ \\ 1 Department of Urology, Catholic University of Daegu School of Medicine, Daegu 42472, Korea; \\ uro.drhah@gmail.com \\ 2 Department of Urology, Gangnam Severance Hospital, Yonsei University College of Medicine, \\ Seoul 06229, Korea \\ * Correspondence: gckoo@yuhs.ac; Tel.: +82-2-2019-3470
}

Citation: Hah, Y.-S.; Koo, K.-C. Immunology and

Immunotherapeutic Approaches for Advanced Renal Cell Carcinoma: A Comprehensive Review. Int. J. Mol. Sci. 2021, 22, 4452. https://doi.org/ $10.3390 /$ ijms22094452

Academic Editors: Marco Erreni and Diletta Di Mitri

Received: 7 March 2021

Accepted: 20 April 2021

Published: 24 April 2021

Publisher's Note: MDPI stays neutral with regard to jurisdictional claims in published maps and institutional affiliations.

Copyright: (c) 2021 by the authors. Licensee MDPI, Basel, Switzerland. This article is an open access article distributed under the terms and conditions of the Creative Commons Attribution (CC BY) license (https:/ / creativecommons.org/licenses/by/ $4.0 /)$.

\begin{abstract}
Renal cell carcinoma (RCC) is a malignant tumor associated with various tumor microenvironments (TMEs). The immune system is activated by the development of cancer and drives $\mathrm{T}$ cell anti-tumor response. CD8 T cells are known to improve clinical outcomes and sensitivity to immunotherapy, and play a crucial role against tumors. In contrast, tumor-associated macrophages (TAMs) suppress immunity against malignancy and lead to tumor progression. TAMs are promoted from damaged TMEs and mount proinflammatory responses to pathogens. Initial immunotherapy consists of interferon- $\alpha$ and interleukin-2. However, response to such therapy is unclear in most patients, and it is associated with high levels of toxicity. Immune checkpoint inhibitors (ICIs), which up-regulate immune responses by blocking the programed cell death protein 1 (PD-1) receptor, the ligand of PD-1, or cytotoxic T-lymphocyte-associated protein $4 \mathrm{~T}$ cells, have led to a new era of immunotherapy. Furthermore, combination strategies with ICIs have proven effective through several randomized controlled trials. We expect the next generation of immunotherapy to lead to better outcomes based on ongoing trials and inspire new therapeutic strategies.
\end{abstract}

Keywords: biomarkers; clinical trials; immune checkpoint inhibitor; immunotherapy; renal cell carcinoma

\section{Introduction}

Renal cell carcinoma (RCC) is the most common type of kidney malignancy, constituting $2-3 \%$ of all cancers. This nephron-arising neoplasm consists of heterogenous subgroups according to histologic and molecular subtypes. Clear cell RCC (ccRCC) is an aggressive subtype, constituting 70-80\% of all RCCs [1]. Von Hippel-Lindau (VHL) is a crucial component for maintaining the oxygen homeostasis of the cellular environment [2]. The loss of the VHL tumor suppressor drives the hypoxic pathway by hypoxia-inducible factors (HIF) transcription factors. It activates several hypoxia-driven genes, such as vascular endothelial growth factor (VEGF), and subsequently induces angiogenesis and cell growth $[3,4]$. This VHL mutation course is the main pathway of ccRCC. Modifications of various genes similarly manifest as other types of RCC. Papillary RCC is the second most common subtype of RCC, and is classified into two subtypes: type I, which is mainly associated with MET alterations, and type II, which is associated with the NRF2-antioxidant response component [5]. Chromophobe RCC is associated with mutations of TP53 and PTEN, while translocation RCC is associated with fusions of TFE3 or TFEB genes [6,7].

Decades ago, there were few options for systemic therapy in advanced RCC. Cytokine therapy, represented by interleukin-2 (IL-2) and interferon alfa (IFN- $\alpha$ ), showed some benefits in a few advanced patients with RCC, but only proved efficacy in a limited proportion of patients [8]. Moreover, cytokine therapy is associated with a high level of toxicity, which limited its general use. With advances in genomic research by the Cancer Genome Atlas (TCGA), targeted molecular therapeutics, specifically tyrosine kinase 
inhibitors (TKIs) targeting the VEGF receptor pathway, have now replaced cytokine therapy and are widely used as first- or second-line therapy. The development of the TCGA also led to a better understanding of the mammalian target of the rapamycin (mTOR) pathway that is known to induce cell growth and division in ccRCC [3,9]. Subsequent development and use of mTOR inhibitors have shown similar oncological outcomes to TKIs [10-12].

Immunity against malignancy varies depending on several components that make up the tumor microenvironment (TME), and therefore clinical symptoms and the course of treatment differ accordingly. RCC is classified as an immunogenic tumor based on its response to immunotherapy, the incidence of spontaneous regression, and a high level of tumor T cell infiltration [13]. Recent advances in immune checkpoint inhibitor (ICI) therapy up-regulating immune responses by blocking the programed cell death protein 1 (PD-1) receptor, ligand of PD-1 (PD-L1) or cytotoxic T-lymphocyte-associated protein 4 (CTLA-4), and T cells have overtaken cytokine-based regimens and are now key players in the field of immunotherapy [14,15]. Unlike IFN- $\alpha$ and IL-2, for which only a limited range of patients are eligible due to toxicity, ICIs are characterized by superior safety profiles and oncological efficacy. Recently, updated guidelines recommend combining VEGF targeted agents with ICIs depending on patient performance and comorbidity.

Risk stratification systems are essential for selecting the optimal treatment for a specific patient. Unfortunately, there are no predictive biomarkers for RCC, which limits effective strategies for management. Current international guidelines for risk stratification rely on clinical variables to guide prognosis and treatment selection. The Memorial Sloan Kettering Cancer Center (MSKCC) criteria incorporate five prognosticators: low performance status, high level of serum dehydrogenase, high level of serum calcium, low concentration of hemoglobin, and interval less than one year from diagnosis to treatment [16]. The International Metastatic Renal Cell Carcinoma Database Consortium (IMDC) utilizes similar prognosticators to those of MSKCC but includes high levels of neutrophil and platelet counts instead of serum lactate dehydrogenase level $[17,18]$. Patients without any corresponding prognostic factors are classified into a low-risk group, patients with one or two prognosticators into an intermediate-risk group, and three or more into a poor-risk group.

In this comprehensive review, we will discuss up-to-date evidence on the microenvironments involved in the development of RCC and how treatment strategies targeted at the host immune system are feasible for controlling disease progression. We summarize progress made regarding systemic treatment, from the cytokine therapy era to the treatment utilizing combined ICIs with or without targeted therapies. Lastly, we summarize ongoing trials involving immunotherapies that will change the landscape of future systemic therapies targeted at advanced RCC.

\section{Tumor Microenvironment in Renal Cell Carcinoma}

Chromosome $3 p$ loss is the first genetic event characterizing sporadic ccRCC, followed by VHL mutation [19]. VHL negatively regulates HIF $1 / 2 \alpha$, which reduce oxygen demand in the cellular environment by increasing glycolytic flux and reducing oxidative phosphorylation. This pathway induces oxygen supply by hyper-vascularization. Based on metabolic pathway analysis by RNA sequencing, ccRCC is known to possess high levels of metabolites during glycolysis and to reduce levels of metabolites associated with oxidative phosphorylation [20]. Hyper-vascularity and the immune system are not independent, and treatment targeting the VEGF receptor promotes the immune pathway by modifying the aberrant blood supply [21].

TME are complicated, containing transformed cells and immune infiltrates. Tumorinfiltrating cells promote or inhibit cancer activity according to the type of cancer. The immune system is activated by cancer development and drives $\mathrm{T}$ cell anti-tumor response by suppressing tumor cells directly, modulating various anti-tumor responses, facilitating the emerging memorial system, and preparing specificity for tumor-derived proteins [8]. $\mathrm{T}$ cell activation, according to immunotherapy response, is a core component in the prognosis of ccRCC. CD8 T cells play a crucial role in combating malignant tumors and are 
associated with favorable clinical outcomes and response to immunotherapy [22-26]. Presentation of major histocompatibility class I (MHC-I) molecules on cancer cells helps $\mathrm{T}$ cell receptors recognize antigens. This pathway activates CD8 $\mathrm{T}$ cells, which subsequently activates antigen-specific immune response, and directly removes antigen-bearing cells [27]. The antigen-presenting machinery (APM) promoted by activated CD8 T cells is a component that interlinks antigens and MHC-I. Upregulation of APM genes refers to the increased production of antigen-presentation and the number of T cells. CcRCC is characterized by the highest $\mathrm{T}$ cell infiltration and immune infiltration when compared to other malignancies. The immunogenicity of ccRCC is related to MHC-I and APM gene expression, which may potentially serve as indicators of response to PD-1 inhibitors. The promotion of APM expression is a unique feature of ccRCC [28]. In contrast, Th2 and regulatory $\mathrm{T}$ cells are negatively associated with prognosis. An abundant environment with Th2 and regulatory T cells suppresses the immune response and is associated with the tumor mutation load [28].

Macrophages are phagocytic innate immune cells that regulate responses to tissue damage. Macrophages are promoted based on consecutive signals from the damaged microenvironment and mount proinflammatory responses to pathogens [29]. Macrophages are abundantly observed in growing cancer cells and mediate lymphocyte trapping according to interactions with CD8 T cells in tumor stroma. Cytokines and chemokines expressed by tumor-associated macrophages (TAMs) suppress immunity against malignancy and lead to tumor progression [30]. In an in vivo study, the efficiency of T cells increased when TAMs were depleted by pexidartinib, a small molecule tyrosine kinase inhibitor that acts against colony-stimulating factor 1 . The depletion of TAMs not only increased the number of tumor-infiltrating CD8 T cells but also improved their migration and ability to reach cancer cells [31-33].

Tertiary lymphoid structures (TLS) are a lymphoid environment usually associated with reactions to infection or inflammation [34]. TLS neogenesis is induced by chronic bacterial or viral infection or by chronic inflammatory diseases such as multiple sclerosis, Sjögren's syndrome, or allograft rejection [35-39]. TME is similar to TLS and includes several components associated with the immune system and $\mathrm{T}$ cell activation. Mature dendritic cells (DCs), which are associated with activated CD8 T cells within the TLS, are associated with favorable survival outcomes in ccRCC. On the other hand, DCs outside of TLS are associated with poor survival outcomes in response to dysfunctional CD8 T cells $[40,41]$.

The wide variety of clinical features and outcomes of immunotherapy in patients with ccRCC are due to the heterogeneity of TME. A study that utilized mass cytometry confirmed the subsets of T cells and TAMs, the critical components of TME [42]. In a study comparing 73 patients with ccRCC and five healthy controls, $20 \mathrm{~T}$ cell phenotypes and 17 TAMs phenotypes were identified. With ongoing research on the mechanisms of treatment failure, TME heterogeneity is being perceived as a key factor.

\section{Immunotherapy in the Early Era}

Late recurrence after partial or radical nephrectomy, long-term stabilization of disease without systemic treatment, and, in rare cases, spontaneous regression suggest that the mechanisms of the host immune system are keystones of controlling tumor growth or suppression [43-46].

IFN- $\alpha$ has been the primary agent used in the early immunotherapy era. The overall response rate to IFN- $\alpha$ has been reported to be low as $12 \%$ [43]. Patients with visceral metastatic RCC, particularly lung RCC, or with prior nephrectomy showed more favorable survival outcomes $[47,48]$. However, maintenance of response was restricted to less than two years [43].

Patients treated with high-dose IL-2 exhibit $4 \%$ complete response (CR), $8 \%$ partial response, and 23 months of response duration. Moreover, high-dose IL-2 was related to severe cardiovascular toxicity due to increased vascular permeability, with treatment- 
related death occurring in $4 \%$ of patients [49,50]. Although oncological outcomes with IFN- $\alpha$ or IL-2 are often dramatic in selected patients, most patients experienced no apparent survival benefit. Hence, these agents are not considered as first- or second-line therapy unless the patient has excellent performance status with normal organ function [8].

Combination therapy consisting of IFN- $\alpha$ and bevacizumab was studied in several trials. Patients with metastatic RCC without previous treatment received IFN- $\alpha$ plus bevacizumab or IFN- $\alpha$ with placebo. Progression-free survival (PFS) was superior in the combination treatment arm. However, no significant improvements were observed in overall survival (OS) during the study period [51-54].

\section{Immune-Associated Novel Prognosticators of Renal Cell Carcinoma}

Recent genomic studies of RCC have developed an understanding of tumor heterogeneity $[3,55,56]$. Much progress has been made in revealing the relationships between the immune system and tumors, but immunotherapy responses differ in each case. Even within a specific type of cancer, a subset of patients will show strong immune infiltration, while others show little or no response to immunotherapy. This heterogeneity suggests that pathological classification alone is insufficient to predict treatment effect and prognosis. A more detailed sub-classification system is warranted [56,57].

Long non-coding RNAs (lncRNAs) are predictors that have become an important focus of debate in recent years $[58,59]$. LncRNAs are non-protein coding RNAs longer than 200 nucleotides $[60,61]$ that are involved in tumor development and suppression by regulating the immune system [62-65]. LncRNAs are more tumor-specific than proteincoding RNAs, inducing up-regulated RCC carcinogenesis, promoting progression and metastasis with a positive-feedback loop [66].

Khadirnaikar et al. found 143 immune-associated lncRNAs genes related to RCC by examining 2378 genes in TCGA RNA sequence data [67]. They divided gene samples into three groups $(\mathrm{C} 1, \mathrm{C} 2$, and $\mathrm{C} 3)$ by $\mathrm{K}$-means consensus clustering according to the expression levels of immune lncRNAs. In a classification according to immune cluster, C3 showed a significantly higher grade of tumor and metastasis and thus poorer prognosis than other groups. These immune clusters yielded better survival prediction rates than those using miRNA or mRNA. The analysis showed increased CD8 T cells and decreased DCs in the C3 cluster when compared to other groups. Patients with C3 showed higher CD8 T cell infiltration; however, they had a worse prognosis due to lack of DC, which plays a role in $\mathrm{T}$ cell activation. On the other hand, in $\mathrm{C} 1$ and $\mathrm{C} 2$, naïve $\mathrm{B}$ cell and neutrophil infiltration associated with a better prognosis were higher than C3 $[68,69]$. Immune infiltration is different depending on the expression level of lncRNAs, which may explain the differences in prognosis.

Molecular subsets of RCC have been redefined according to differential clinical responses to angiogenesis blockade with or without ICI [70,71]. Motzer et al. performed transcriptomic analysis of advanced RCC tumor samples, which revealed seven subsets with distinct angiogenesis, immune, cell-cycle, metabolism, and stromal programs. Clinical benefits with sunitinib and atezolizumab plus bevacizumab were observed in patients with high angiogenesis, while atezolizumab plus bevacizumab was beneficial in patients with high T-effector and/or cell-cycle transcription [57]. Overall, the results implied that RCC may be molecularly classified to stratify patients for the optimal oncological outcome.

\section{Immune Checkpoint Inhibitors for Renal Cell Carcinoma}

Blockades of immune checkpoint components such as PD-1/PD-L1 and CTLA-4 have shown considerable oncological benefit and have shifted treatment strategies targeted at RCC. Clinical trials involving ICIs are summarized in Table 1.

CheckMate 025 was a phase III, open-label, randomized study that compared nivolumab with everolimus. A total of 821 patients with advanced ccRCC who had received previous anti-angiogenic therapy were randomly allocated to receive nivolumab $(3 \mathrm{mg} / \mathrm{kg})$ every two weeks or everolimus (10 mg) daily [72]. The median OS was favorable for nivolumab 
when compared to everolimus ( 25.0 months vs. 19.6 months; HR $0.73 ; 98.5 \%$ confidence interval $[\mathrm{CI}] 0.57-0.93 ; p=0.002$ ). The objective response rate (ORR) was also superior in the nivolumab arm ( $25 \%$ vs. $5 \%$; $95 \%$ CI $3.68-9.72 ; p<0.001)$. However, PFS was comparable in both treatment arms (4.6 months vs. 4.4 months; HR 0.88; 95\% CI 0.75-1.03; $p=0.11$ ). Superior quality-of-life (QoL) was observed in patients treated with nivolumab, with fewer treatment-related adverse events (TRAEs) of grade 3 or 4 (19\% vs. 37\%) [73].

Sunitinib and pazopanib are common first-line agents used for patients with advanced RCC. The recent development of combination treatments with ICIs is changing treatment paradigms, especially for intermediate-risk or poor-risk patients. CheckMate 214 was a phase III study that compared nivolumab and ipilimumab with sunitinib for patients with treatment-naïve advanced ccRCC [74]. A total of 1096 patients were allocated at a 1:1 ratio to nivolumab $(3 \mathrm{mg} / \mathrm{kg})$ every two weeks and ipilimumab $(1 \mathrm{mg} / \mathrm{kg})$ every three weeks or sunitinib (50 mg) daily for four weeks (6-week cycle). In patients with intermediate-risk or poor-risk group by the IMDC criteria, the median OS was not reached in the combination group, while 26 months was achieved in the sunitinib group (HR 0.63; $p<0.001$ ). The ORR was superior in the combination group compared to the sunitinib group a $42 \%$ versus $27 \%(p<0.001)$. CR rates were also favorable in the combination group compared to the sunitinib group ( $9 \%$ vs. $1 \% ; p<0.001)$. Median PFS was improved with combination therapy (11.6 months vs. 8.4 months; HR 0.82; $p=0.03$ ); however, it did not satisfy the prespecified statistical threshold (alpha level $=0.009$ ). Grade 3 or 4 TRAEs were observed in $46 \%$ of the patients in the nivolumab and ipilimumab combination group, while $63 \%$ of the patients in the sunitinib group. The patients were administered FKSI-19 questionnaires to access health-related QoL, which revealed that the combination arm experienced more significant improvement from baseline than the sunitinib arm $(p<0.001)$. ORR was lower in the combination arm than the sunitinib arm $(29 \%$ vs. $52 \% ; p<0.001)$. Median PFS was also inferior in the combination arm than in the sunitinib arm (15.3 months vs. 25.1 months; HR for progressive disease or death, 2.18; 99.1\% CI, 1.29-3.68; $p<0.001$ ).

IMmotion151 was a phase III, open-label, randomized study that compared atezolizumab plus bevacizumab with sunitinib for chemotherapy-naïve advanced RCC patients with clear cell or sarcomatoid pathology [75,76]. A total of 915 patients were randomly allocated at a 1:1 ratio to atezolizumab $(1200 \mathrm{mg})$ and bevacizumab $(15 \mathrm{mg} / \mathrm{kg})$ every three weeks or sunitinib $(50 \mathrm{mg}$ ) daily for four weeks (6-week cycle). Overall, $40 \%$ of the patients exhibited PD-L1 expression, with more than $1 \%$ in tumor-infiltrating immune cells. In PD-L1 positive patients, the median PFS was superior in the combination arm compared to the sunitinib arm (11.2 months vs. 7.7 months; HR 0.74; 95\% CI 0.57-0.96; $p=0.022$ ). The intention-to-treat (ITT) cohort exhibited similar favorable results in the combination arm (11.2 months vs. 8.4 months; HR $0.83 ; 95 \%$ CI $0.70-0.97 ; p=0.022)$. However, median OS was comparable in both PD-L1 positive (HR 0.84; 95\% CI 0.62-1.15; $p=0.286$ ) and in ITT patients (HR 0.93; 95\% CI 0.76-1.14; $p=0.475$ ) in the second interim analysis. In subgroup analyses, PD-L1 positive patients who were administered atezolizumab plus bevacizumab exhibited superior PFS regardless of MSKCC and IMDC risk classification criteria. Previous nephrectomy and the absences of liver metastasis and sarcomatoid histology were factors associated with favorable PFS in the combination arm. ORR was superior with atezolizumab plus bevacizumab (43\%) than with sunitinib (35\%) in PD-L1 positive patients. The rate of $\mathrm{CR}$ was comparable between the combination versus the sunitinib arms ( $9 \%$ vs. $4 \%$ ). Grade 3 or 4 TRAEs were noted in $40 \%$ of patients in the combination arm and $54 \%$ of patients in the sunitinib arm.

JAVELIN Renal 101 also involved a combination of ICIs as the first-line of therapy [77]. This phase III trial involved 886 patients with treatment-naïve advanced RCC and randomized patients at a 1:1 ratio to compare avelumab $(10 \mathrm{mg} / \mathrm{kg})$ every two weeks plus axitinib $(5 \mathrm{mg})$ twice daily with sunitinib $(50 \mathrm{mg}$ ) once daily for four weeks (6-week cycle). In the PD-L1 positive patients, the median PFS was favorable for avelumab plus axitinib compared to sunitinib (13.8 months vs. 7.2 months; HR $0.61 ; 95 \%$ CI $0.47-0.79 ; p<0.001$ ). The ORR in the avelumab and axitinib group was higher than that of the sunitinib group 
in both the PD-L1 positive group and the overall group (55.2\% vs. $25.5 \%$ and $51.4 \%$ vs. $25.7 \%$, respectively). The rate of CR was also higher in the combination group in both the PD-L1 positive group and in the overall group (12\% vs. $6 \%$ and $15 \%$ vs. $8 \%$, respectively). TRAEs appeared in $99.5 \%$ of patients who received avelumab plus axitinib, but in $99.3 \%$ of patients who received sunitinib. More patients needed subsequent therapy after sunitinib compared to combination therapy (39.2\% vs. $20.8 \%)$.

Table 1. Phase III clinical trials investigating combination immune checkpoint inhibitor therapies for advanced renal cell carcinoma.

\begin{tabular}{|c|c|c|c|c|c|c|}
\hline Trial & Agents & Clinical Setting & OS (Months) & PFS (Months) & ORR (\%) & TRAEs $(\%)$ * \\
\hline CheckMate 025 [72] & Nivolumab vs. Everolimus & Second-line & $\begin{array}{c}25.0 \text { vs. } 19.6 \\
(p=0.002)\end{array}$ & $\begin{array}{l}4.6 \text { vs. } 4.4 \\
(p=0.11)\end{array}$ & $\begin{array}{l}25.0 \text { vs. } 5.0 \\
(p<0.001)\end{array}$ & 19.0 vs. 37.0 \\
\hline CheckMate 214 [74] & $\begin{array}{l}\text { Nivolumab + Ipilimumab vs. } \\
\text { Sunitinib }\end{array}$ & $\begin{array}{c}\text { First-line } \\
\text { Intermediate- or } \\
\text { poor-risk }\end{array}$ & $\begin{array}{l}\text { Not reached vs. } 26.0 \\
\quad(p<0.001)\end{array}$ & $\begin{array}{l}11.6 \text { vs. } 8.4 \\
(p=0.03) * \\
\end{array}$ & $\begin{array}{c}42.0 \text { vs. } 27.0 \\
(p<0.001)\end{array}$ & 46.0 vs. 63.0 \\
\hline IMmotion 151 [75] & $\begin{array}{c}\text { Atezolizumab }+ \\
\text { Bevacizumab vs. Sunitinib }\end{array}$ & $\begin{array}{l}\text { First-line } \\
\text { PD-L1 +, ITT }\end{array}$ & $\begin{array}{c}34.0 \text { vs. } 32.7^{\dagger} \\
(p=0.286)\end{array}$ & $\begin{array}{l}11.2 \text { vs. } 7.7 \\
(p=0.0217)\end{array}$ & 43.0 vs. 35.0 & 40.0 vs. 54.0 \\
\hline $\begin{array}{c}\text { JAVELIN Renal } \\
101 \text { [77] }\end{array}$ & $\begin{array}{l}\text { Avelumab + Axitinib vs. } \\
\text { Sunitinib }\end{array}$ & $\begin{array}{l}\text { First-line } \\
\text { PD-L1 + }\end{array}$ & $\begin{array}{c}\text { Patients continued } \\
\text { to be followed }\end{array}$ & $\begin{array}{l}13.8 \text { vs. } 7.2 \\
(p<0.001)\end{array}$ & $\begin{array}{c}55.2 \text { vs. } 25.5 \\
\ddagger\end{array}$ & 71.2 vs. 71.5 \\
\hline KEYNOTE-426 [78] & $\begin{array}{l}\text { Pembrolizumab + Axitinib vs. } \\
\text { Sunitinib }\end{array}$ & First-line & $\begin{array}{l}\text { Not reached in both } \\
\text { groups }\end{array}$ & $\begin{array}{c}15.1 \text { vs. } 11.1 \\
(p<0.001)\end{array}$ & $\begin{array}{c}59.3 \text { vs. } 35.7 \\
(p<0.001)\end{array}$ & 62.9 vs. 58.1 \\
\hline
\end{tabular}

* Treatment-related adverse event grade 3 or $4 . * *$ Not significant per the prespecified alpha level 0.009 threshold. ${ }^{\dagger}$ Not estimated at the second interim analysis. $¥$ The stratified odds ratio 3.73. ITT, intention-to-treatment; ORR, objective response rate; OS, overall survival; PD-L1, programed death-ligand 1; PFS, progression-free survival; TRAEs, treatment-related adverse events.

KEYNOTE-426 was a phase III study that compared pembrolizumab plus axitinib with sunitinib. A total of 861 patients with chemotherapy-naïve, advanced RCC were randomly allocated at a 1:1 ratio to receive pembrolizumab (200 $\mathrm{mg})$ every three weeks with axitinib (5 mg) twice daily or sunitinib (50 mg) daily for four weeks (6-week cycle) [78]. The estimated survival rate at 12 months was $89.9 \%$ in the pembrolizumab plus axitinib arm and $78.3 \%$ in the sunitinib arm. The median survival was not reached in both arms; however, the possibility of death was significantly lower in the combination therapy arm (HR 0.53; 95\% CI 0.38-0.74; $p<0.001$ ). The median PFS was four months longer in the pembrolizumab and axitinib arm than in the sunitinib arm (15.1 months vs. 11.1 months; HR 0.69; 95\% CI 0.57-0.84; $p<0.001$ ). The survival advantages of pembrolizumab plus axitinib were observed regardless of IMDC risk classification and PD-L1 expression. The ORR and CR were superior in the combination arm compared to the sunitinib arm (59.3\% vs. $35.7 \% ; p<0.001$ and $5.8 \%$ vs. $1.9 \%$, respectively). Subsequent chemotherapy was needed in $50.0 \%$ of patients in the pembrolizumab plus axitinib arm and in $60.7 \%$ of the patients in the sunitinib arm. TRAEs were observed in $96.3 \%$ of the patients in the pembrolizumab-axitinib arm and $97.6 \%$ of the patients in the sunitinib arm. Notably, the rate of grade 3 or higher TRAEs was higher in the pembrolizumab-axitinib arm than the sunitinib arm $(62.9 \%$ vs. $58.1 \%$ ). An extended study with a median follow-up of 30.6 months also showed benefits in the pembrolizumab plus axitinib combination arm [71]. The OS was not reached in the pembrolizumab-axitinib arm, while 35.7 months was observed in the sunitinib arm within the ITT population (HR 0.68; 95\% CI 0.55-0.85; $p<0.001$ ). In this extended exploratory analysis, patients with favorable-risk based on the IMDC criteria showed no difference in OS (HR 1.06; 95\% CI 0.60-1.86; $p=0.58$ ), while patients with intermediate-risk or poor-risk showed significant benefit (HR 0.63; 95\% CI 0.50-0.81; $p<0.001$ ).

\section{Ongoing Trials Involving Immune Checkpoint Inhibitors}

Several phase III clinical trials involving ICIs are ongoing and are expecting results [79]. A summary of these ongoing trials is presented in Table 2. 
Table 2. Ongoing phase III clinical trials investigating first-line therapies for advanced renal cell carcinoma.

\begin{tabular}{|c|c|c|c|}
\hline Trial & Identifier & Comparing Agents & Primary Endpoint \\
\hline $\begin{array}{l}\text { KEYNOTE-679/ } \\
\text { ECHO-302 [80] }\end{array}$ & NCT03260894 & Pembrolizumab + Epacadostat vs. Sunitinib or Pazopanib & ORR \\
\hline CLEAR [81] & NCT02811861 & Lenvatinib $+($ Everolimus or Pembrolizumab) vs. Sunitinib & PFS \\
\hline CheckMate 9ER [82] & NCT03141177 & Nivolumab + Cabozantinib \pm Ipilimumab vs. Sunitinib & PFS \\
\hline COSMIC-313 [83] & NCT03937219 & $\begin{array}{c}\text { Cabozantinib + Nivolumab + Ipilimumab vs. Nivolumab + } \\
\text { Ipilimumab }\end{array}$ & PFS \\
\hline PDIGREE [84] & NCT03793166 & $\begin{array}{c}\text { Nivolumab + Ipilimumab } \rightarrow \text { Nivolumab + Cabozantinib vs. } \\
\text { Nivolumab }\end{array}$ & OS \\
\hline CONTACT-03 [85] & NCT04338269 & $\begin{array}{c}\text { (Atezolizumab or Avelumab or Nivolumab or } \\
\text { Pembrolizumab) } \rightarrow \text { PD } \rightarrow \text { Atezolizumab + Cabozantinib vs. } \\
\text { Cabozantinib }\end{array}$ & OS, PFS \\
\hline CheckMate 914 [86] & NCT03138512 & $\begin{array}{c}\text { Radial or partial nephrectomy } \rightarrow \text { Nivolumab } \pm \text { Ipilimumab } \\
\text { vs. Placebo }\end{array}$ & DFS \\
\hline NORDIC-SUN [87] & NCT03977571 & $\begin{array}{c}\text { Cytoreductive nephrectomy }+ \text { Nivolumab }+ \text { Ipilimumab } \rightarrow \\
\text { Nivolumab vs. No surgery }+ \text { Nivolumab }+ \text { Ipilimumab } \rightarrow \\
\text { Nivolumab }\end{array}$ & OS \\
\hline PROSPER RCC [88] & NCT03055013 & $\begin{array}{l}\text { Radical or partial nephrectomy + perioperative Nivolumabvs. } \\
\text { Radial or partial nephrectomy only }\end{array}$ & PFS \\
\hline RAMPART [89] & NCT03288532 & $\begin{array}{c}\text { Radical or partial nephrectomy } \rightarrow \text { (Active monitoring vs. } \\
\text { Durvalumab vs. Durvalumab + Tremelimumab) }\end{array}$ & DFS, OS \\
\hline
\end{tabular}

DFS; disease-free survival, ORR, objective response rate; PD, progressive disease; PFS, progression-free survival.

KEYNOTE-679/ECHO-302 is a phase III, open-label, randomized controlled trial comparing pembrolizumab plus epacadostat with standard TKI treatment such as sunitinib or pazopanib in patients with treatment-naïve, locally advanced or metastatic ccRCC (NCT03260894) [80]. Patients of the combination therapy group receive pembrolizumab $(200 \mathrm{mg})$ intravenously every three weeks and epacadostat $(100 \mathrm{mg})$ orally twice daily. Standard-of-care patients receive sunitinib $(50 \mathrm{mg}$ ) once daily for four weeks (6-week cycle) or pazopanib $800 \mathrm{mg}$ once daily. The primary endpoint is ORR, while the secondary endpoints are safety and tolerability.

CLEAR is a phase III randomized study comparing lenvatinib in combination with everolimus or pembrolizumab versus sunitinib alone in the first-line setting of advanced RCC (NCT02811861) [81]. Patients who receive lenvatinib (18 mg) daily plus everolimus $(5 \mathrm{mg})$ daily or lenvatinib $(20 \mathrm{mg})$ daily plus pembrolizumab $(200 \mathrm{mg})$ every three weeks are compared with patients who receive sunitinib $(50 \mathrm{mg}$ ) once daily for four weeks (6-week cycle). The primary endpoint is PFS, and the secondary endpoints are ORR, OS, TRAEs, health-related QoL, and PFS until the next-line of therapy.

CheckMate 9ER is a phase III, open-label, randomized trial of nivolumab combined with cabozantinib versus sunitinib in patients with previously untreated advanced or metastatic RCC (NCT03141177) [82]. The primary endpoint is PFS, and the secondary endpoints are OS, ORR, and TRAEs.

COSMIC-313 is a phase III, double-blind, randomized trial comparing cabozantinib in combination with nivolumab and ipilimumab (four doses) versus nivolumab and ipilimumab (four doses) in patients with treatment-naïve, advanced or metastatic ccRCC of intermediate-risk or poor-risk (NCT03937219) [83]. The primary endpoint is PFS, and the secondary is OS.

PDIGREE is a phase III, open-label, randomized trial comparing nivolumab and ipilimumab followed by nivolumab versus cabozantinib with nivolumab in patients with untreated metastatic RCC (NCT03793166) [84]. Patients receive nivolumab and ipilimumab intravenously every three weeks for up to four cycles. Patients with progressive disease receive cabozantinib daily until further disease progression or unacceptable toxicity. Patients with CR continue nivolumab intravenously every four weeks. Patients with a non-CR and non-progressive disease receive nivolumab intravenously every four weeks or nivolumab every four weeks plus cabozantinib daily in the absence of disease progression or unac- 
ceptable toxicity. The primary endpoint is OS, and the secondary endpoints are PFS, CR, ORR, TRAEs.

CONTACT-03 is a phase III, open-label, randomized trial to investigate the efficacy and safety of atezolizumab plus cabozantinib versus cabozantinib monotherapy in patients with inoperable, locally advanced, or metastatic RCC who exhibit radiographic tumor progression during or after ICI treatment (NCT04338269) [85]. Patients with disease progression after treatment of atezolizumab, avelumab, pembrolizumab, or nivolumab receive atezolizumab $(1200 \mathrm{mg})$ every three weeks with cabozantinib $(60 \mathrm{mg})$ orally once daily or cabozantinib alone. The primary endpoints are PFS and OS. Ongoing trials associated with surgical treatments are summarized in Table 2 [86-89].

\section{Summary and Future Directions}

Advancements in ICIs have led to improved therapeutic efficacy and safety for various types of tumors, including advanced RCC. The immune mechanisms underlying the development and progression of RCC make ICIs the most valuable potential systemic therapy in RCC management.

Early cytokine immunotherapy played an important role in the management of advanced RCC, but its high toxicity profile and low response rate limited its widespread use. TKIs targeting the VEGF receptor pathway have made significant advancements in TKIs without adverse events. Newly developed ICIs and their combined treatments have shown favorable results in terms of oncological outcomes and safety profiles and are currently recommended as first-line therapy.

Cytokines and chemokines expressed by TAMs suppress anti-tumor immune mechanisms, leading to tumor progression [30,90,91]. Furthermore, TAMs are known strongly associated with resistance to TKIs and ICIs. Specific pathways regulating the recruitment, polarization, and metabolism of TAMs have been identified in preclinical studies [92].

Understanding TME is an important step in understanding immune mechanisms involved in RCC development. TKI inhibits the process in which mutations of the VHL gene induces HIF to accelerate VEGF for neovasculation and tumor development. Novel approaches are underway to develop biomarkers associated with TAM and to integrate novel radiomic modalities. Accumulation of mannosylated liposome containing fluorescent dye in TAMs has been demonstrated in a mouse model of lung carcinoma [93]. This indicates that mannose-coated liposomes combined with therapeutic agents could be delivered to TME. A pilot study that quantified TAM using ferumoxytol-enhanced MRI illustrated the possibility that TME could be accessed with modified MR technology [94]. New approaches and applications of functional and structural imaging for RCC are being investigated, and are expected to be useful decision-making tools in the near future [95-97].

Recent trials have shown that combined ICI therapies are oncologically superior to single-agent targeted therapies in terms of OS and PFS outcomes as well as TRAEs profiles. Future studies are warranted to elucidate the optimal combination and sequencing of these agents for maximal survival benefit. Further research on novel diagnostic modalities remains to be performed.

Author Contributions: Conceptualization, Y.-S.H. and K.-C.K.; writing-original draft preparation, Y.-S.H.; writing - review and editing, K.-C.K.; supervision and project administration, K.-C.K. Both authors have read and agreed to the published version of the manuscript.

Funding: This research received no external funding.

Acknowledgments: This study was supported by the Research Grant of the National Research Foundation of Korea (2020R1F1A1073833) and the Research Grant of Gangnam Severance Hospital Urological Research Committee (7523110).

Conflicts of Interest: The authors declare no conflict of interest. 


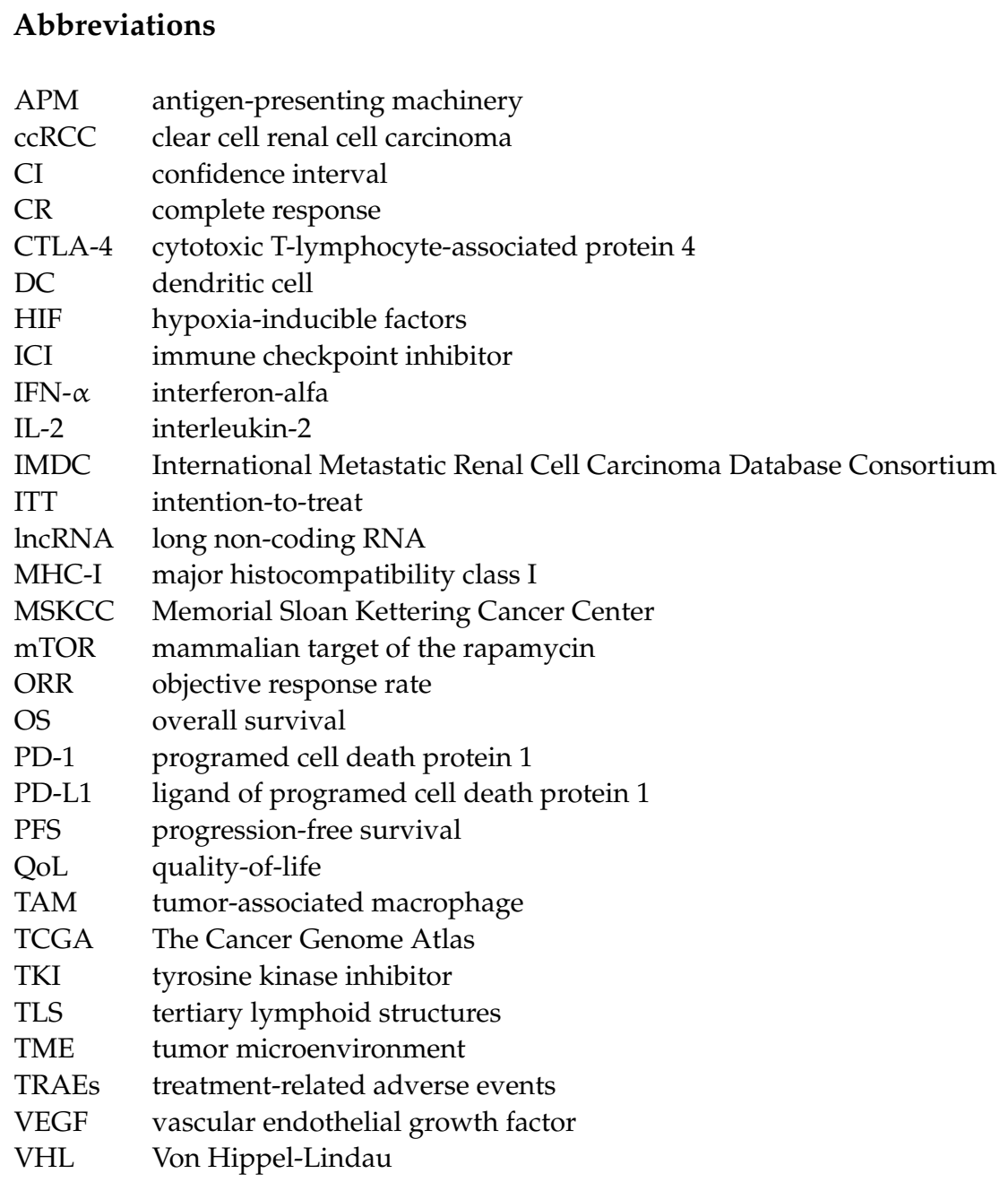

\section{References}

1. Linehan, W.M. Genetic basis of kidney cancer: Role of genomics for the development of disease-based therapeutics. Genome Res. 2012, 22, 2089-2100. [CrossRef] [PubMed]

2. Latif, F.; Tory, K.; Gnarra, J.; Yao, M.; Duh, F.-M.; Orcutt, M.L.; Stackhouse, T.; Kuzmin, I.; Modi, W.; Geil, L.; et al. Identification of the von hippel-lindau disease tumor suppressor gene. Science 1993, 260, 1317-1320. [CrossRef]

3. Network, C.G.A.R. Comprehensive molecular characterization of clear cell renal cell carcinoma. Nature 2013, $499,43-49$.

4. Kaelin, W.G., Jr. The von hippel-lindau tumour suppressor protein: $\mathrm{O}_{2}$ sensing and cancer. Nat. Rev. Cancer $2008,8,865-873$. [CrossRef] [PubMed]

5. Network, C.G.A.R. Comprehensive molecular characterization of papillary renal-cell carcinoma. N. Engl. J. Med. 2016, 374, 135-145.

6. Davis, C.F.; Ricketts, C.J.; Wang, M.; Yang, L.; Cherniack, A.D.; Shen, H.; Buhay, C.; Kang, H.; Kim, S.C.; Fahey, C.C.; et al. The somatic genomic landscape of chromophobe renal cell carcinoma. Cancer Cell 2014, 26, 319-330. [CrossRef]

7. Malouf, G.G.; Monzon, F.A.; Couturier, J.; Molinié, V.; Escudier, B.; Camparo, P.; Su, X.; Yao, H.; Tamboli, P.; Lopez-Terrada, D.; et al. Genomic heterogeneity of translocation renal cell carcinoma. Clin. Cancer Res. 2013, 19, 4673-4684. [CrossRef]

8. Motzer, R.J.; Bander, N.H.; Nanus, D.M. Renal-cell carcinoma. N. Engl. J. Med. 1996, 335, 865-875. [CrossRef]

9. Sabatini, D.M. mTOR and cancer: Insights into a complex relationship. Nat. Rev. Cancer 2006, 6, 729-734. [CrossRef]

10. Kwiatkowski, D.J.; Manning, B.D. Molecular basis of giant cells in tuberous sclerosis complex. N. Engl. J. Med. 2014, 371, 778-780. [CrossRef]

11. Yu, Y.; Yoon, S.-O.; Poulogiannis, G.; Yang, Q.; Ma, X.M.; Villén, J.; Kubica, N.; Hoffman, G.R.; Cantley, L.C.; Gygi, S.P.; et al. Phosphoproteomic analysis identifies Grb10 as an mTORC1 substrate that negatively regulates insulin signaling. Science 2011, 332, 1322-1326. [CrossRef] [PubMed]

12. Motzer, R.J.; Escudier, B.; Oudard, S.; Hutson, T.E.; Porta, C.; Bracarda, S.; Grünwald, V.; Thompson, J.A.; Figlin, R.A.; Hollaender, N.; et al. Efficacy of everolimus in advanced renal cell carcinoma: A double-blind, randomised, placebo-controlled phase III trial. Lancet 2008, 372, 449-456. [CrossRef] 
13. Vuong, L.; Kotecha, R.R.; Voss, M.H.; Hakimi, A.A. Tumor microenvironment dynamics in clear-cell renal cell carcinoma. Cancer Discov. 2019, 9, 1349-1357. [CrossRef] [PubMed]

14. Harshman, L.C.; Drake, C.G.; Choueiri, T.K. PD-1 blockade in renal cell carcinoma: To equilibrium and beyond. Cancer Immunol. Res. 2014, 2, 1132-1141. [CrossRef]

15. Rosenblatt, J.; McDermott, D.F. Immunotherapy for renal cell carcinoma. Hematol. Oncol. Clin. N. Am. 2011, 25, 793-812. [CrossRef]

16. Motzer, R.J.; Mazumdar, M.; Bacik, J.; Berg, W.; Amsterdam, A.; Ferrara, J. Survival and prognostic stratification of 670 patients with advanced renal cell carcinoma. J. Clin. Oncol. 1999, 17, 2530. [CrossRef]

17. Heng, D.Y.; Xie, W.; Regan, M.M.; Warren, M.A.; Golshayan, A.R.; Sahi, C.; Eigl, B.J.; Ruether, J.D.; Cheng, T.; North, S.; et al. Prognostic factors for overall survival in patients with metastatic renal cell carcinoma treated with vascular endothelial growth factor-targeted agents: Results from a large, multicenter study. J. Clin. Oncol. 2009, 27, 5794-5799. [CrossRef] [PubMed]

18. Heng, D.Y.; Xie, W.; Regan, M.M.; Harshman, L.C.; Bjarnason, G.A.; Vaishampayan, U.N.; Mackenzie, M.; Wood, L.; Donskov, F.; Tan, M.-H.; et al. External validation and comparison with other models of the international metastatic renal-cell carcinoma database consortium prognostic model: A population-based study. Lancet Oncol. 2013, 14, 141-148. [CrossRef]

19. Hsieh, J.J.; Le, V.H.; Oyama, T.; Ricketts, C.J.; Ho, T.H.; Cheng, E.H. Chromosome 3p loss-orchestrated VHL, HIF, and epigenetic deregulation in clear cell renal cell carcinoma. J. Clin. Oncol. 2018, 36, 3533. [CrossRef]

20. Hakimi, A.A.; Reznik, E.; Lee, C.-H.; Creighton, C.J.; Brannon, A.R.; Luna, A.; Aksoy, B.A.; Liu, E.M.; Shen, R.; Lee, W.; et al. An integrated metabolic atlas of clear cell renal cell carcinoma. Cancer Cell 2016, 29, 104-116. [CrossRef]

21. Fukumura, D.; Kloepper, J.; Amoozgar, Z.; Duda, D.G.; Jain, R.K. Enhancing cancer immunotherapy using antiangiogenics: Opportunities and challenges. Nat. Rev. Clin. Oncol. 2018, 15, 325. [CrossRef]

22. Galon, J.; Costes, A.; Sanchez-Cabo, F.; Kirilovsky, A.; Mlecnik, B.; Lagorce-Pagès, C.; Tosolini, M.; Camus, M.; Berger, A.; Wind, P.; et al. Type, density, and location of immune cells within human colorectal tumors predict clinical outcome. Science 2006, 313, 1960-1964. [CrossRef]

23. Galon, J.; Fridman, W.-H.; Pagès, F. The adaptive immunologic microenvironment in colorectal cancer: A novel perspective. Cancer Res. 2007, 67, 1883-1886. [CrossRef]

24. Pagès, F.; Kirilovsky, A.; Mlecnik, B.; Asslaber, M.; Tosolini, M.; Bindea, G.; Lagorce, C.; Wind, P.; Marliot, F.; Bruneval, P.; et al. In situ cytotoxic and memory t cells predict outcome in patients with early-stage colorectal cancer. J. Clin. Oncol. 2009, 27, 5944-5951. [CrossRef]

25. Tumeh, P.C.; Harview, C.L.; Yearley, J.H.; Shintaku, I.P.; Taylor, E.J.; Robert, L.; Chmielowski, B.; Spasic, M.; Henry, G.; Ciobanu, V.; et al. PD-1 blockade induces responses by inhibiting adaptive immune resistance. Nature 2014, 515, 568-571. [CrossRef]

26. Gajewski, T.F.; Schreiber, H.; Fu, Y.-X. Innate and adaptive immune cells in the tumor microenvironment. Nat. Immunol. 2013, 14, 1014-1022. [CrossRef]

27. Neefjes, J.; Jongsma, M.L.; Paul, P.; Bakke, O. Towards a systems understanding of MHC class I and MHC class II antigen presentation. Nat. Rev. Immunol. 2011, 11, 823-836. [CrossRef]

28. Şenbabaoğlu, Y.; Gejman, R.S.; Winer, A.G.; Liu, M.; Van Allen, E.M.; de Velasco, G.; Miao, D.; Ostrovnaya, I.; Drill, E.; Luna, A.; et al. Tumor immune microenvironment characterization in clear cell renal cell carcinoma identifies prognostic and immunotherapeutically relevant messenger RNA signatures. Genome Biol. 2016, 17, 1-25. [CrossRef]

29. Yuri, P.; Shigemura, K.; Kitagawa, K.; Hadibrata, E.; Risan, M.; Zulfiqqar, A.; Soeroharjo, I.; Hendri, A.Z.; Danarto, R.; Ishii, A.; et al. Increased tumor-associated macrophages in the prostate cancer microenvironment predicted patients' survival and responses to androgen deprivation therapies in Indonesian patients cohort. Prostate Int. 2020, 8, 62-69. [CrossRef]

30. Pathria, P.; Louis, T.L.; Varner, J.A. Targeting tumor-associated macrophages in cancer. Trends Immunol. 2019, 40, 310-327. [CrossRef]

31. Peranzoni, E.; Lemoine, J.; Vimeux, L.; Feuillet, V.; Barrin, S.; Kantari-Mimoun, C.; Bercovici, N.; Guérin, M.; Biton, J.; Ouakrim, H.; et al. Macrophages impede CD8 T cells from reaching tumor cells and limit the efficacy of anti-PD-1 treatment. Proc. Natl. Acad. Sci. USA 2018, 115, E4041-E4050. [CrossRef] [PubMed]

32. Dagher, N.N.; Najafi, A.R.; Kayala, K.M.N.; Elmore, M.R.; White, T.E.; Medeiros, R.; West, B.L.; Green, K.N. Colony-stimulating factor 1 receptor inhibition prevents microglial plaque association and improves cognition in 3xTg-AD mice. J. Neuroinflamm. 2015, 12, 139. [CrossRef]

33. Tap, W.D.; Wainberg, Z.A.; Anthony, S.P.; Ibrahim, P.N.; Zhang, C.; Healey, J.H.; Chmielowski, B.; Staddon, A.P.; Cohn, A.L.; Shapiro, G.I.; et al. Structure-guided blockade of CSF1R kinase in tenosynovial giant-cell tumor. N. Engl. J. Med. 2015, 373, 428-437. [CrossRef] [PubMed]

34. Dieu-Nosjean, M.-C.; Goc, J.; Giraldo, N.A.; Sautès-Fridman, C.; Fridman, W.H. Tertiary lymphoid structures in cancer and beyond. Trends Immunol. 2014, 35, 571-580. [CrossRef] [PubMed]

35. Neyt, K.; Perros, F.; GeurtsvanKessel, C.H.; Hammad, H.; Lambrecht, B.N. Tertiary lymphoid organs in infection and autoimmunity. Trends Immunol. 2012, 33, 297-305. [CrossRef]

36. Lucchesi, D.; Bombardieri, M. The role of viruses in autoreactive B cell activation within tertiary lymphoid structures in autoimmune diseases. J. Leukoc. Biol. 2013, 94, 1191-1199. [CrossRef] [PubMed] 
37. Magliozzi, R.; Howell, O.; Vora, A.; Serafini, B.; Nicholas, R.; Puopolo, M.; Reynolds, R.; Aloisi, F. Meningeal B-cell follicles in secondary progressive multiple sclerosis associate with early onset of disease and severe cortical pathology. Brain 2007, 130, 1089-1104. [CrossRef] [PubMed]

38. Le Pottier, L.; Devauchelle, V.; Fautrel, A.; Daridon, C.; Saraux, A.; Youinou, P.; Pers, J.-O. Ectopic germinal centers are rare in sjögren's syndrome salivary glands and do not exclude autoreactive B cells. J. Immunol. 2009, 182, 3540-3547. [CrossRef] [PubMed]

39. Baddoura, F.K.; Nasr, I.W.; Wrobel, B.; Li, Q.; Ruddle, N.H.; Lakkis, F.G. Lymphoid neogenesis in murine cardiac allografts undergoing chronic rejection. Am. J. Transplant. 2005, 5, 510-516. [CrossRef]

40. Giraldo, N.A.; Becht, E.; Vano, Y.; Petitprez, F.; Lacroix, L.; Validire, P.; Sanchez-Salas, R.; Ingels, A.; Oudard, S.; Moatti, A.; et al. Tumor-infiltrating and peripheral blood T-cell immunophenotypes predict early relapse in localized clear cell renal cell carcinoma. Clin. Cancer Res. 2017, 23, 4416-4428. [CrossRef]

41. Giraldo, N.A.; Becht, E.; Pages, F.; Skliris, G.; Verkarre, V.; Vano, Y.; Mejean, A.; Saint-Aubert, N.; Lacroix, L.; Natario, I.; et al. Orchestration and prognostic significance of immune checkpoints in the microenvironment of primary and metastatic renal cell cancer. Clin. Cancer Res. 2015, 21, 3031-3040. [CrossRef] [PubMed]

42. Chevrier, S.; Levine, J.H.; Zanotelli, V.R.T.; Silina, K.; Schulz, D.; Bacac, M.; Ries, C.H.; Ailles, L.; Jewett, M.A.S.; Moch, H.; et al. An immune atlas of clear cell renal cell carcinoma. Cell 2017, 169, 736-749.e718. [CrossRef]

43. Iyer, M.K.; Niknafs, Y.S.; Malik, R.; Singhal, U.; Sahu, A.; Hosono, Y.; Barrette, T.R.; Prensner, J.R.; Evans, J.R.; Zhao, S.; et al. The landscape of long noncoding rnas in the human transcriptome. Nat. Genet. 2015, 47, 199-208. [CrossRef]

44. Sahu, A.; Singhal, U.; Chinnaiyan, A.M. Long noncoding RNAs in cancer: From function to translation. Trends Cancer 2015, 1, 93-109. [CrossRef]

45. Perkel, J.M. Visiting “noncodarnia". Biotechniques 2013, 301, 303-304. [CrossRef] [PubMed]

46. Cabianca, D.S.; Casa, V.; Bodega, B.; Xynos, A.; Ginelli, E.; Tanaka, Y.; Gabellini, D. A long ncRNA links copy number variation to a polycomb/trithorax epigenetic switch in FSHD muscular dystrophy. Cell 2012, 149, 819-831. [CrossRef] [PubMed]

47. Prensner, J.R.; Chinnaiyan, A.M. The emergence of lncRNAs in cancer biology. Cancer Discov. 2011, 1, 391-407. [CrossRef]

48. Wang, K.C.; Yang, Y.W.; Liu, B.; Sanyal, A.; Corces-Zimmerman, R.; Chen, Y.; Lajoie, B.R.; Protacio, A.; Flynn, R.A.; Gupta, R.A.; et al. A long noncoding RNA maintains active chromatin to coordinate homeotic gene expression. Nature 2011, 472, 120-124. [CrossRef]

49. Zhao, L.; Ji, G.; Le, X.; Wang, C.; Xu, L.; Feng, M.; Zhang, Y.; Yang, H.; Xuan, Y.; Yang, Y.; et al. Long noncoding RNA linc00092 acts in cancer-associated fibroblasts to drive glycolysis and progression of ovarian cancer. Cancer Res. 2017, 77, 1369-1382. [CrossRef] [PubMed]

50. Zhou, M.; Zhao, H.; Xu, W.; Bao, S.; Cheng, L.; Sun, J. Discovery and validation of immune-associated long non-coding RNA biomarkers associated with clinically molecular subtype and prognosis in diffuse large b cell lymphoma. Mol. Cancer 2017, 16, 1-13. [CrossRef] [PubMed]

51. Zhai, W.; Zhu, R.; Ma, J.; Gong, D.; Zhang, H.; Zhang, J.; Chen, Y.; Huang, Y.; Zheng, J.; Xue, W. A positive feed-forward loop between lncRNA-URRCC and EGFL7/P-AKT/FOXO3 signaling promotes proliferation and metastasis of clear cell renal cell carcinoma. Mol. Cancer 2019, 18, 81. [CrossRef]

52. Khadirnaikar, S.; Kumar, P.; Pandi, S.N.; Malik, R.; Dhanasekaran, S.M.; Shukla, S.K. Immune associated lncRNAs identify novel prognostic subtypes of renal clear cell carcinoma. Mol. Carcinog. 2019, 58, 544-553. [CrossRef]

53. Treffers, L.W.; Hiemstra, I.H.; Kuijpers, T.W.; Van den Berg, T.K.; Matlung, H.L. Neutrophils in cancer. Immunol. Rev. 2016, 273, 312-328. [CrossRef] [PubMed]

54. Wikberg, M.L.; Ling, A.; Li, X.; Öberg, Å.; Edin, S.; Palmqvist, R. Neutrophil infiltration is a favorable prognostic factor in early stages of colon cancer. Hum. Pathol. 2017, 68, 193-202. [CrossRef] [PubMed]

55. Gerlinger, M.; Horswell, S.; Larkin, J.; Rowan, A.J.; Salm, M.P.; Varela, I.; Fisher, R.; McGranahan, N.; Matthews, N.; Santos, C.R.; et al. Genomic architecture and evolution of clear cell renal cell carcinomas defined by multiregion sequencing. Nat. Genet. 2014, 46, 225. [CrossRef]

56. Chen, F.; Zhang, Y.; Şenbabaoğlu, Y.; Ciriello, G.; Yang, L.; Reznik, E.; Shuch, B.; Micevic, G.; De Velasco, G.; Shinbrot, E.; et al. Multilevel genomics-based taxonomy of renal cell carcinoma. Cell Rep. 2016, 14, 2476-2489. [CrossRef]

57. Motzer, R.J.; Banchereau, R.; Hamidi, H.; Powles, T.; McDermott, D.; Atkins, M.B.; Escudier, B.; Liu, L.F.; Leng, N.; Abbas, A.R.; et al. Molecular subsets in renal cancer determine outcome to checkpoint and angiogenesis blockade. Cancer Cell 2020, $38,803-817$. [CrossRef]

58. Wirth, M. Immunotherapy for metastatic renal cell carcinoma. Urol. Clin. N. Am. 1993, 20, 283. [CrossRef]

59. Rosenberg, S.A.; Lotze, M.T.; Muul, L.M.; Chang, A.E.; Avis, F.P.; Leitman, S.; Linehan, W.M.; Robertson, C.N.; Lee, R.E.; Rubin, J.T.; et al. A progress report on the treatment of 157 patients with advanced cancer using lymphokine-activated killer cells and interleukin-2 or high-dose interleukin-2 alone. N. Engl. J. Med. 1987, 316, 889-897. [CrossRef]

60. Law, T.M.; Motzer, R.J.; Mazumdar, M.; Sell, K.W.; Walther, P.; O'Connell, M.; Khan, A.; Vlamis, V.; Vogelzang, N.J.; Bajorin, D.F. Phase III randomized trial of interleukin-2 with or without lymphokine-activated killer cells in the treatment of patients with advanced renal cell carcinoma. Cancer 1995, 76, 824-832. [CrossRef]

61. Vogelzang, N.J.; Lipton, A.; Figlin, R.A. Subcutaneous interleukin-2 plus interferon alfa-2a in metastatic renal cancer: An outpatient multicenter trial. J. Clin. Oncol. 1993, 11, 1809-1816. [CrossRef] 
62. Minasian, L.M.; Motzer, R.J.; Gluck, L.; Mazumdar, M.; Vlamis, V.; Krown, S.E. Interferon alfa-2a in advanced renal cell carcinoma: Treatment results and survival in 159 patients with long-term follow-up. J. Clin. Oncol. 1993, 11, 1368-1375. [CrossRef] [PubMed]

63. Fossä, S.; Martinelli, G.; Otto, U.; Schneider, G.; Wander, H.; Oberling, F.; Bauer, H.; Achtnicht, U.; Holdener, E. Recombinant interferon alfa-2a with or without vinblastine in metastatic renal cell carcinoma: Results of a european multi-center phase III study. Ann. Oncol. 1992, 3, 301-305. [CrossRef] [PubMed]

64. Fyfe, G.; Fisher, R.I.; Rosenberg, S.A.; Sznol, M.; Parkinson, D.R.; Louie, A.C. Results of treatment of 255 patients with metastatic renal cell carcinoma who received high-dose recombinant interleukin-2 therapy. J. Clin. Oncol. 1995, 13, 688-696. [CrossRef] [PubMed]

65. Allard, C.B.; Gelpi-Hammerschmidt, F.; Harshman, L.C.; Choueiri, T.K.; Faiena, I.; Modi, P.; Chung, B.I.; Tinay, I.; Singer, E.A.; Chang, S.L. Contemporary trends in high-dose interleukin-2 use for metastatic renal cell carcinoma in the united states. Urol. Oncol. 2015, 33, 496.e11-496.e16. [CrossRef]

66. Escudier, B.; Pluzanska, A.; Koralewski, P.; Ravaud, A.; Bracarda, S.; Szczylik, C.; Chevreau, C.; Filipek, M.; Melichar, B.; Bajetta, E.; et al. Bevacizumab plus interferon alfa-2a for treatment of metastatic renal cell carcinoma: A randomised, double-blind phase III trial. Lancet 2007, 370, 2103-2111. [CrossRef]

67. Escudier, B.; Bellmunt, J.; Négrier, S.; Bajetta, E.; Melichar, B.; Bracarda, S.; Ravaud, A.; Golding, S.; Jethwa, S.; Sneller, V. Phase III trial of bevacizumab plus interferon alfa-2a in patients with metastatic renal cell carcinoma (avoren): Final analysis of overall survival. J. Clin. Oncol. 2010, 28, 2144-2150. [CrossRef]

68. Rini, B.I.; Halabi, S.; Rosenberg, J.E.; Stadler, W.M.; Vaena, D.A.; Ou, S.-S.; Archer, L.; Atkins, J.N.; Picus, J.; Czaykowski, P.; et al. Bevacizumab plus interferon alfa compared with interferon alfa monotherapy in patients with metastatic renal cell carcinoma: CALGB 90206. J. Clin. Oncol. 2008, 26, 5422. [CrossRef]

69. Rini, B.I.; Halabi, S.; Rosenberg, J.E.; Stadler, W.M.; Vaena, D.A.; Archer, L.; Atkins, J.N.; Picus, J.; Czaykowski, P.; Dutcher, J.; et al. Phase III trial of bevacizumab plus interferon alfa versus interferon alfa monotherapy in patients with metastatic renal cell carcinoma: Final results of CALGB 90206. J. Clin. Oncol. 2010, 28, 2137. [CrossRef]

70. Brunet, J.P.; Tamayo, P.; Golub, T.R.; Mesirov, J.P. Metagenes and molecular pattern discovery using matrix factorization. Proc. Natl. Acad. Sci. USA 2004, 101, 4164-4169. [CrossRef]

71. Powles, T.; Plimack, E.R.; Soulières, D.; Waddell, T.; Stus, V.; Gafanov, R.; Nosov, D.; Pouliot, F.; Melichar, B.; Vynnychenko, I.; et al. Pembrolizumab plus axitinib versus sunitinib monotherapy as first-line treatment of advanced renal cell carcinoma (KEYNOTE-426): Extended follow-up from a randomised, open-label, phase 3 trial. Lancet Oncol. 2020, 21, 1563-1573. [CrossRef]

72. Motzer, R.J.; Escudier, B.; McDermott, D.F.; George, S.; Hammers, H.J.; Srinivas, S.; Tykodi, S.S.; Sosman, J.A.; Procopio, G.; Plimack, E.R. Nivolumab versus everolimus in advanced renal-cell carcinoma. N. Engl. J. Med. 2015, 373, 1803-1813. [CrossRef]

73. Choueiri, T.K.; Escudier, B.; Powles, T.; Mainwaring, P.N.; Rini, B.I.; Donskov, F.; Hammers, H.; Hutson, T.E.; Lee, J.-L.; Peltola, K.; et al. Cabozantinib versus everolimus in advanced renal-cell carcinoma. N. Engl. J. Med. 2015, 373, 1814-1823. [CrossRef]

74. Motzer, R.J.; Tannir, N.M.; McDermott, D.F.; Frontera, O.A.; Melichar, B.; Choueiri, T.K.; Plimack, E.R.; Barthélémy, P.; Porta, C.; George, S.; et al. Nivolumab plus ipilimumab versus sunitinib in advanced renal-cell carcinoma. N. Engl. J. Med. 2018, 378, 1277-1290. [CrossRef] [PubMed]

75. Rini, B.I.; Powles, T.; Atkins, M.B.; Escudier, B.; McDermott, D.F.; Suarez, C.; Bracarda, S.; Stadler, W.M.; Donskov, F.; Lee, J.L.; et al. Atezolizumab plus bevacizumab versus sunitinib in patients with previously untreated metastatic renal cell carcinoma (immotion151): A multicentre, open-label, phase 3, randomised controlled trial. Lancet 2019, 393, 2404-2415. [CrossRef]

76. Motzer, R.J.; Powles, T.; Atkins, M.B.; Escudier, B.; McDermott, D.F.; Suarez, C.; Bracarda, S.; Stadler, W.M.; Donskov, F.; Lee, J.-L.; et al. Immotion151: A randomized phase III study of atezolizumab plus bevacizumab vs sunitinib in untreated metastatic renal cell carcinoma (mrcc). J. Clin. Oncol. Am. Soc. Clin. Oncol. 2018, 36, 578. [CrossRef]

77. Motzer, R.J.; Penkov, K.; Haanen, J.; Rini, B.; Albiges, L.; Campbell, M.T.; Venugopal, B.; Kollmannsberger, C.; Negrier, S.; Uemura, M.; et al. Avelumab plus axitinib versus sunitinib for advanced renal-cell carcinoma. N. Engl. J. Med. 2019, 380, 1103-1115. [CrossRef]

78. Rini, B.I.; Plimack, E.R.; Stus, V.; Gafanov, R.; Hawkins, R.; Nosov, D.; Pouliot, F.; Alekseev, B.; Soulières, D.; Melichar, B.; et al. Pembrolizumab plus axitinib versus sunitinib for advanced renal-cell carcinoma. N. Engl. J. Med. 2019, 380, 1116-1127. [CrossRef] [PubMed]

79. Hofmann, F.; Hwang, E.C.; Lam, T.B.; Bex, A.; Yuan, Y.; Marconi, L.S.; Ljungberg, B. Targeted therapy for metastatic renal cell carcinoma. Cochrane Database Syst. Rev. 2020. [CrossRef]

80. US National Library of Medicine. A Randomized, Open-Label, Phase 3 Study to Evaluate Efficacy and Safety of Pembrolizumab (MK-3475) Plus Epacadostat vs Standard of Care (Sunitinib or Pazopanib) as First-Line Treatment for Locally Advanced or Metastatic Renal Cell Carcinoma. Available online: https://clinicaltrials.gov/ct2/show/NCT03260894 (accessed on 1 March 2021).

81. US National Library of Medicine. A Multicenter, Open-Label, Randomized, Phase 3 Trial to Compare the Efficacy and Safety of Lenvatinib in Combination with Everolimus or Pembrolizumab Versus Sunitinib Alone in First-Line Treatment of Subjects with Advanced Renal Cell Carcinoma. Available online: https://clinicaltrials.gov/ct2/show/NCT02811861 (accessed on 1 March 2021). 
82. US National Library of Medicine. A Phase 3, Randomized, Open-Label Study of Nivolumab Combined with Cabozantinib Versus Sunitinib in Participants with Previously Untreated Advanced or Metastatic Renal Cell Carcinoma. Available online: https:/ / clinicaltrials.gov/ct2/show / NCT03141177 (accessed on 1 March 2021).

83. US National Library of Medicine. A Randomized, Double-Blind, Controlled Phase 3 Study of Cabozantinib in Combination with Nivolumab and Ipilimumab Versus Nivolumab and Ipilimumab in Subjects with Previously Untreated Advanced or Metastatic Renal Cell Carcinoma of Intermediate or Poor Risk. Available online: https://clinicaltrials.gov/ct2/show/NCT03937219 (accessed on 1 March 2021).

84. US National Library of Medicine. PD-Inhibitor (Nivolumab) and Ipilimumab Followed by Nivolumab vs. VEGF TKI Cabozantinib with Nivolumab: A Phase III Trial in Metastatic Untreated Renal Cell Cancer. Available online: https://clinicaltrials.gov/ct2 / show / NCT03793166 (accessed on 1 March 2021).

85. US National Library of Medicine. A Phase III, Multicenter, Randomized, Open-Label Study to Evaluate the Efficacy and Safety of Atezolizumab Given in Combination with Cabozantinib Versus Cabozantinib Alone in Patients with Inoperable, Locally Advanced, or Metastatic Renal Cell Carcinoma Who Experienced Radiographic Tumor Progression during or after Immune Checkpoint Inhibitor Treatment. Available online: https: / clinicaltrials.gov/ct2/show / NCT04338269 (accessed on 1 March 2021).

86. US National Library of Medicine. A Phase 3 Randomized, Double-Blind Study of Nivolumab Monotherapy or Nivolumab Combined with Ipilimumab vs Placebo in Participants with Localized Renal Cell Carcinoma Who Underwent Radical or Partial Nephrectomy and Who Are at High Risk of Relapse. Available online: https://clinicaltrials.gov/ct2/show/NCT03138512 (accessed on 31 March 2021).

87. US National Library of Medicine. Multicenter Randomized Phase III Trial of Deferred Cytoreductive Nephrectomy in Synchronous Metastatic Renal Cell Carcinoma Receiving Checkpoint Inhibitors: A DaRenCa and NoRenCa Trial Evaluating the Impact of Surgery or No Surgery: The NORDIC-SUN-Trial. Available online: https:/ / clinicaltrials.gov /ct2/show / NCT03977571 (accessed on 31 March 2021).

88. US National Library of Medicine. A Phase 3 RandOmized Study Comparing PERioperative Nivolumab vs. Observation in Patients with Renal Cell Carcinoma Undergoing Nephrectomy (PROSPER RCC). Available online: https:/ clinicaltrials.gov / ct2 / show / NCT03055013 (accessed on 31 March 2021).

89. US National Library of Medicine. An International Investigator-led Phase III Multi Arm Multi Stage Multi-centre Randomised Controlled Platform Trial of Adjuvant Therapy in Patients with Resected Primary Renal Cell Carcinoma (RCC) at High or Intermediate Risk of Relapse. Available online: https: / clinicaltrials.gov/ct2/show / NCT03288532 (accessed on 31 March 2021).

90. Sawa-Wejksza, K.; Kandefer-Szerszeń, M. Tumor-associated macrophages as target for antitumor therapy. Arch. Immunol. Ther. Exp. 2018, 66, 97-111. [CrossRef]

91. Petty, A.J.; Yang, Y. Tumor-associated macrophages: Implications in cancer immunotherapy. Immunotherapy 2017, 9, $289-302$. [CrossRef] [PubMed]

92. Schmid, M.C.; Khan, S.Q.; Kaneda, M.M.; Pathria, P.; Shepard, R.; Louis, T.L.; Anand, S.; Woo, G.; Leem, C.; Faridi, M.H.; et al. Integrin CD11b activation drives anti-tumor innate immunity. Nat. Commun. 2018, 9, 1-14. [CrossRef] [PubMed]

93. Locke, L.W.; Mayo, M.W.; Yoo, A.D.; Williams, M.B.; Berr, S.S. PET imaging of tumor associated macrophages using mannose coated 64Cu liposomes. Biomaterials 2012, 33, 7785-7793. [CrossRef] [PubMed]

94. Iv, M.; Samghabadi, P.; Holdsworth, S.; Gentles, A.; Rezaii, P.; Harsh, G.; Li, G.; Thomas, R.; Moseley, M.; Daldrup-Link, H.E.; et al. Quantification of macrophages in high-grade gliomas by using ferumoxytol-enhanced mri: A pilot study. Radiology 2019, 290, 198-206. [CrossRef] [PubMed]

95. Yin, Q.; Hung, S.-C.; Wang, L.; Lin, W.; Fielding, J.R.; Rathmell, W.K.; Khandani, A.H.; Woods, M.E.; Milowsky, M.I.; Brooks, S.A.; et al. Associations between tumor vascularity, vascular endothelial growth factor expression and PET/MRI radiomic signatures in primary clear-cell-renal-cell-carcinoma: Proof-of-concept study. Sci. Rep. 2017, 7, 43356. [CrossRef] [PubMed]

96. Yin, Q.; Hung, S.-C.; Rathmell, W.K.; Shen, L.; Wang, L.; Lin, W.; Fielding, J.R.; Khandani, A.H.; Woods, M.E.; Milowsky, M.I.; et al. Integrative radiomics expression predicts molecular subtypes of primary clear cell renal cell carcinoma. Clin. Radiol. 2018, 73, 782-791. [CrossRef]

97. Baldewijns, M.; Thijssen, V.; Van den Eynden, G.; Van Laere, S.; Bluekens, A.; Roskams, T.; Van Poppel, H.; De Bruine, A.; Griffioen, A.; Vermeulen, P. High-grade clear cell renal cell carcinoma has a higher angiogenic activity than low-grade renal cell carcinoma based on histomorphological quantification and qRT-PCR mRNA expression profile. Br. J. Cancer 2007, 96, 1888-1895. [CrossRef] 